\title{
Effect of bacterial filters on spirometry measurements
}

\author{
A W A Kamps, K Vermeer, R J Roorda, P L P Brand
}

\begin{abstract}
Lung function measurements with and without a disposable bacterial filter were compared in 60 children. Although statistically significant, the reduction of lung function measurements caused by using bacterial filters was small and clinically irrelevant $(2-4 \%$ of predicted for forced expiratory volume in one second and vital capacity).

(Arch Dis Child 2001;85:346-347)
\end{abstract}

Keywords: lung function; bacterial filters; asthma; cystic fibrosis

Measurements of pulmonary function are frequently performed in children with pulmonary disease. Cross infection with resistant microorganisms between patients through contamination of lung function equipment is of particular concern in patients with cystic fibrosis $(\mathrm{CF})$. To avoid this, disposable bacterial filters can be used. ${ }^{1}$ The introduction of a disposable bacterial filter for measurements of pulmonary function in patients with $\mathrm{CF}$ has led to a reduction of colonisation with Burkholderia cepacia from $8 \%$ to $0 \% .^{2}$ It has, therefore, been advised to use bacterial filters routinely when performing lung function tests. ${ }^{1}$ Studies in adults have shown small but significant reductions in expired flow and volume when using a filter. ${ }^{3}$ In this study we investigated the effect of two disposable bacterial filters on spirometry measurements in children.

\section{Methods and results}

Lung function was performed according to European Respiratory Society guidelines ${ }^{5}$ in 60 (30 for each filter) consecutive asthmatic patients (aged $6-14$ years, 40 boys) visiting our outpatient clinic for a scheduled follow up visit. In each patient, at least three reproducible full expiratory flow-volume curves were obtained with a Jaeger Masterlab pneumotachograph (Erich Jaeger GmbH, Würzburg, Germany). The effect of the filters on forced expiratory volume in one second $\left(\mathrm{FEV}_{1}\right)$, forced vital capacity (FVC), maximal expiratory flow when $50 \%$ of FVC has been expired $\left(\mathrm{MEF}_{50}\right)$, and

Department of Paediatrics, Isala Klinieken, PO Box 10500, 8000 GM Zwolle, Netherlands

A W A Kamps

K Vermeer

R J Roorda

P L P Brand

Correspondence to: Dr Brand

P.L.P.Brand@isala.n

Accepted 11 June 2001

Values are presented as mean (SD)\% predicted. obtaining flow-volume curves with and without a filter, in random order. Values are presented as a percentage of predicted. ${ }^{6}$ Two bacterial filters were tested: Microgard (Sensormedics, Bilthoven, Netherlands), and VitalGard (Vital Signs, Bath, UK). The expiratory resistance for the MicroGard and the VitalGard filter, as reported by the manufacturer, was $<0.7 \mathrm{~cm} \mathrm{H}_{2} \mathrm{O} 1 / \mathrm{s}$ at $121 / \mathrm{s}$, and $0.25 \mathrm{~cm}$ $\mathrm{H}_{2} \mathrm{O} 1 / \mathrm{s}$ at $12 \mathrm{l} / \mathrm{s}$, respectively. The filter volumes were $50 \mathrm{ml}$ and $75 \mathrm{ml}$, respectively. Results of lung function parameters obtained with and without a filter were compared with paired $t$ tests, and those between filters with unpaired $t$ tests.

Patients' characteristics were comparable between the two filter groups. Table 1 presents results of the lung function measurements with and without the filters. Values for $\mathrm{FEV}_{1}, \mathrm{FVC}$, $\mathrm{PEF}$, and $\mathrm{MEF}_{50}$ were all slightly, but significantly lower with than without the MicroGard filter. With the VitalGard filter, only $\mathrm{FEV}_{1}$, FVC, and PEF were significantly reduced. There were no significant differences between the amounts of reduction of pulmonary function caused by the two filters. The difference in $\mathrm{FEV}_{1}$ between measurements with and without a filter were not correlated with $\mathrm{FEV}_{1}$ level; this was also true for FVC, $\mathrm{PEF}$, and $\mathrm{MEF}_{50}$.

\section{Discussion}

In agreement with results obtained in adults, ${ }^{34}$ we found statistically significant reductions in expiratory flow and volume when applying disposable bacterial filters during measurement of lung function in children. Although significant, differences between measurements with and without a filter were small, amounting to $2-4 \%$ of predicted for $\mathrm{FEV}_{1}, \mathrm{MEF}_{50}$, and $\mathrm{FVC}$, and approximately $6 \%$ for PEF. The clinical relevance of such differences is negligible. Our results, therefore, suggest that the use of bacterial filters does not influence measurements and interpretation of pulmonary function in school aged children in any meaningful way. In research, however, differences in the order of magnitude as those we found caused by bacterial filters could be important, and lung function results obtained with and without a

Table 1 Lung function measurements without and with two disposable bacterial filters

\begin{tabular}{|c|c|c|c|c|c|c|}
\hline & \multicolumn{3}{|l|}{ MicroGard } & \multicolumn{3}{|l|}{ VitalGard } \\
\hline & Without & With & Mean difference $(95 \% \mathrm{CI})$ & Without & With & Mean difference $(95 \%$ CI) \\
\hline $\mathrm{FEV}_{1}$ & $97.0(18.5)$ & $94.6(18.0)$ & $-2.4(-3.6$ to -1.3$)$ & $104.4(11.0)$ & $102.6(10.9)$ & $-2.8(-3.9$ to -1.8$)$ \\
\hline $\mathrm{MEF}_{50}$ & $79.1(24.7)$ & $75.9(22.4)$ & $-3.2(-5.7$ to -0.7$)$ & $82.6(20.8)$ & $82.4(19.3)$ & $-0.2(-2.9$ to 2.5$)$ \\
\hline PEF & $92.4(18.4)$ & $86.4(15.4)$ & $-6.1(-8.1$ to -4.0$)$ & $95.5(13.1)$ & $89.3(12.4)$ & $-6.2(-9.1$ to -4.1$)$ \\
\hline FVC & $94.6(14.3)$ & $92.3(14.6)$ & $-2.2(-3.3$ to -1.2$)$ & $101.8(9.7)$ & $98.2(10.0)$ & $-3.5(-5.2$ to -1.9$)$ \\
\hline
\end{tabular}


filter should be analysed separately. This is of particular importance in multicentre studies. Our study population comprised asthmatic children in a clinically stable condition, with well maintained pulmonary function. Although unlikely, it is possible that the effect of bacterial filters on spirometry measurements is larger in patients with seriously reduced lung function, and further studies in such a population are needed.

In conclusion, this study shows significant, but small and clinically irrelevant reductions in expiratory flow and volume measurements caused by the use of bacterial filters in lung function equipment in children.
1 Clausen JL. Lung volume equipment and infection control. ERS/ATS workshop report series. European Respiratory Society/American Thoracic Society. Eur Respir 7 1997;10:1928-32.

2 Jacques I, Derelle J, Weber M, Vidailhet M. Pulmonary evolution of cystic fibrosis patients colonized by Pseudomonas aeruginosa and/or Burkholderia cepacia. Eur 7 Pediatr 1998;157:427-31.

3 Fuso L, Accardo D, Bevignani G, et al. Effects of a filter at the mouth on pulmonary function tests. Eur Respir 7 1995; 8:314-17

4 Johns DP, Ingram C, Booth $\mathrm{H}$, et al. Effect of a microaerosol barrier filter on the measurement of lung function. Chest 1995;107:1045-8.

5 Standardized lung function testing: official statement of the European Respiratory Society. Eur Respir F 1993;16(suppl): 1-100.

6 Zapletal A. Lung function in children and adolescents. Methods, reference values. In: Zapletal A, Samanak M, Paul T, eds. Progress in respiration research. Basel: Karger, 1987:114-218.

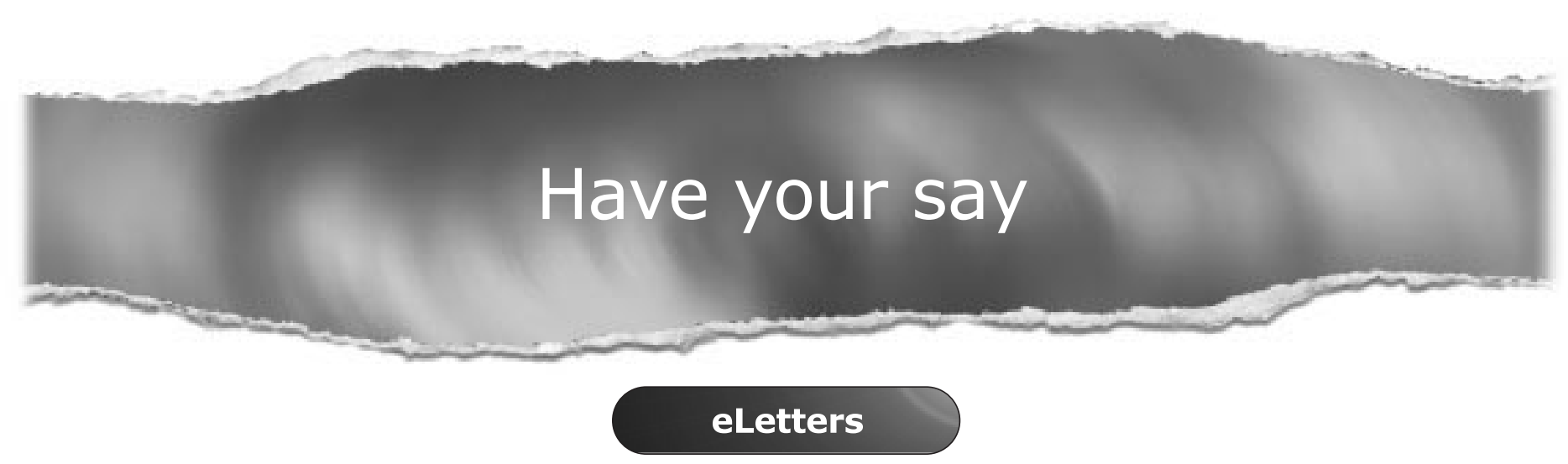

If you wish to comment on any article published in Archives of Disease in Childhood you can send an eLetter using the eLetters link at the beginning of each article. Your response will be posted on Archives of Disease in Childhood online within a few days of receipt (subject to editorial screening).

www.archdischild.com 